\title{
Ekspresi COX-2 dan Jumlah Neutrofil Fase Inflamasi pada Proses Penyembuhan Luka Setelah Pemberian Sistemik Ekstrak Etanolik Rosela (Hibiscus sabdariffa) (studi in vivo pada Tikus Wistar)
}

\author{
Endah Kusumastuti*, Juni Handajani**, dan Heni Susilowati** \\ *Fakultas Kedokteran Gigi Institut IImu Kesehatan Bhakti Wiyata Kediri. \\ ${ }^{* *}$ Fakultas Kedokteran Gigi Universitas Gadjah Mada \\ Jl. KH. Wachid Hasyim No. 65, Kediri, Jawa Timur, Indonesia; e-mail: endah_drg@ymail.com
}

\begin{abstract}
ABSTRAK
Inflamasi merupakan respon alami tubuh terhadap adanya kerusakan jaringan. Salah satu medikamen untuk mengatasi inflamasi adalah antiinflamasi non steroid (AINS). Penggunaan AINS mempunyai beberapa efek samping dan dalam beberapa hal penggunaan tanaman obat dinilai lebih aman. Rosela merupakan salah satu tanaman obat yang mempunyai potensi sebagai antiinflamasi. Penelitian ini bertujuan untuk mengetahui efek pemberian sistemik ekstrak etanolik rosela terhadap ekspresi COX-2 dan jumlah neutrofil fase inflamasi pada proses penyembuhan luka. Bunga rosela didapatkan dari perkebunan di Dusun Bulusari Desa Pojok Kecamatan Tarokan Kabupaten Kediri Jawa Timur. Pembuatan ekstrak rosela dilakukan di LPPT unit I UGM Yogjakarta dengan cara perkolasi. Tikus putih galur Wistar sebanyak 36 ekor diberi perlukaan dengan punch biopsi e $3 \mathrm{~mm}$ pada mukosa bukal. Subjek dibagi menjadi 3 kelompok, masing-masing kelompok 12 ekor tikus. Pembagian kelompok terdiri dari kontrol negatif (saline), kontrol positif (ibuprofen $20 \mathrm{mg} / \mathrm{kg}$ $\mathrm{BB}$ ) dan perlakuan (ekstrak rosela $500 \mathrm{mg} / \mathrm{kg} \mathrm{BB}$ ). Pemberian minum sesuai kelompoknya sehari sekali selama 4 hari. Pada hari ke-1, ke-2, ke-3 dan ke-4 tikus dikorbankan lalu jaringan mukosa yang mengalami perlukaan dibuat preparat histologis. Pewarnaan Hematoksilin Eosin (HE) dilakukan untuk mengamati jumlah neutrofil. Ekspresi COX-2 diamati pada preparat dengan pewarnaan imunohistokimia menggunakan rabbit polyclonal antibody COX-2 (Lab Vision, USA). Jumlah neutrofil dan ekspresi COX-2 dihitung di bawah mikroskop cahaya lalu data dianalisi menggunakan ANAVA dan LSD. Hasil penelitian menunjukkan bahwa ekspresi COX-2 dan jumlah neutrofil lebih rendah pada kelompok perlakuan dibanding kontrol. Pengamatan klinis pada hari ke-4 juga tampak luka seluruh subjek telah menutup sempurna setelah pemberian minum rosela. Disimpulkan bahwa ekstrak etanolik rosela mempunyai kemampuan menghambat ekspresi COX-2 dan menurunkan jumlah neutrofil sehingga dapat digunakan sebagai bahan anti-inflamasi.

Maj Ked Gi. Juni 2014; 21(1): 13 - 19.
\end{abstract}

Kata kunci: ekstrak etanolik rosela (Hibiscus sabdariffa), ekspresi COX-2, jumlah neutrofil, penyembuhan luka

ABSTRACT: Expression of COX-2 and The Number of Neutrophil in Inflammation stage of Wound Healing Process after Systemic Administration of Ethanolic Extract Rosela. Inflammation is an initial stage of body's natural response to tissue damage. The use empirically plants often used for traditional medicine because it is easily found in the community and fewer side effects. Flavanoid presence of roselle (Hibiscus sabdariffa) is thought to have antiinflammatory effects. This study aimed to know the effect of systemic administration of Roselle ethanolic extract toward COX-2 expression and neutrophils number in the inflammatory phase of wound healing processes. Roselle was obtained from plantations in Bulusari hamlet, Tarokan, Kediri, EastJava. Making roselle extract was performed in LPPT unit 1 UGM Yogyakarta by percolation ways. Wistar rats were given a total of 36 injuries with e $3 \mathrm{~mm}$ punch biopsy of the buccal mucosa. Subjects were divided into three groups, each group of 12 rats. The division consists of the negative control group (saline), positive control (ibuprofen $20 \mathrm{mg} / \mathrm{kg}$ ) and treatment (roselle extract $500 \mathrm{mg} / \mathrm{kg}$ ). Giving drink suitable group once daily for four days. On day 1, the 2 nd, 3rd and fourth rats were sacrificed, and mucosal tissue injury was made histological preparat. Hematoxylin eosin staining (HE) was performed to observe the number of neutrophils. COX-2 expression was found in preparations for immunohistochemical staining using rabbit polyclonal COX-2 antibody (Lab Vision, USA). The number of neutrophils and expression of COX-2 is calculated under a light microscope data were analyzed using Two-way ANOVA and LSD. The results showed that the expression of COX-2 and neutrophil number were least in the treatment group compared to the control. Clinical observation on day four also appears around the wound has completely closed the subject after administration of roselle drink. It was concluded that the ethanolic extract of roselle can inhibit COX-2 expression and decrease the number of neutrophils that can be used as an anti-inflammatory ingredient.

Maj Ked Gi. Juni 2014; 21(1): 13 - 19.

Keywords: ethanolic extract of rosella (Hibiscus sabdariffa), expression of COX-2, neutrophils numbers, wound healing 


\section{PENDAHULUAN}

Perlukaan jaringan lunak rongga mulut banyak dijumpai pada pasien di klinik gigi. Luka akan diikuti proses penyembuhan luka yang kompleks terdiri dari beberapa tahap yang saling berhubungan. Proses tersebut diawali dengan terjadinya perdarahan proses selanjutnya adalah fase inflamasi, proliferasi dan remodeling. ${ }^{1}$

Inflamasi menyebabkan banyak zat-zat yang dikeluarkan secara endogen, dikenal sebagai mediator inflamasi. Asam arakidonat merupakan salah satu mediator inflamasi yang penting, asam arakidonat berperan dalam biosintesis prostaglandin melalui jalur siklooksigenase. ${ }^{2}$ Siklooksigenase-1 (COX-1) berperan pada fungsi fisiologis normal seperti sekresi mukus untuk melindungi mukosa pencernaan dan untuk memelihara fungsi ginjal.

Siklooksigenase-2 (COX-2) merupakan enzim yang keberadaanya dipengaruhi adanya rangsangan pada jaringan. Rangsangan tersebut dapat berupa sitokin, lipopolisakarida bakteri, inflamasi atau keadaan patologis lainnya. ${ }^{3}$ Inflamasi juga mengakibatkan penimbunan sel darah putih, terutama neutrofil dan monosit pada lokasi jejas untuk menghilangkan atau membatasi agen penyebab jejas. Neutrofil akan melakukan marginasi, emigrasi, kemotaksis dan fagositosis. ${ }^{2}$

Kontrol terhadap rasa sakit dan edema akan meningkatkan respon imun dalam penyembuhan luka sehingga penyembuhan luka berlangsung lebih baik. Salah satu cara mengontrol rasa sakit dan edema adalah dengan menghambat enzim siklooksigenase. Obat anti inflamasi non steroid (AINS), contohnya ibuprofen bekerja sebagai antiinflamasi dengan cara menghambat enzim siklooksigenase dan menghambat migrasi sel-sel inflamasi dan ekspresi adhesi sel. ${ }^{4,5}$ Penggunaan AINS dapat menimbulkan efek samping, diantaranya dapat menyebabkan terjadinya perdarahan gastrointestinal, memperlama waktu perdarahan, serta dapat merusak fungsi ginjal. ${ }^{6,7}$

Penggunaan tanaman tradisional lebih aman dari pada penggunaan obat kimiawi sintetis. Salah satu tanaman obat tradisional yang mempunyai potensi sebagai antiinflamasi adalah rosela. Adanya kandungan komponen-komponen kimia alami seperti fenol, alkaloid, tanin, flavanoid, saponin dan antioksidan yang tinggi dalam rosela menyebabkan rosela memiliki khasiat untuk mencegah berbagai penyakit seperti kanker, hipertensi, diabetes, kolesterol, gangguan liver, asam urat, anti virus, anti bakteri dan anti inflamasi. ${ }^{8,9}$ Penelitian secara in vivo pada tikus yang diinduksi dengan caragenan memperlihatkan rosela mempunyai kemampuan sebagai antiinflamasi. ${ }^{10}$ Penelitian secara in vitro untuk mengkaji potensi antioksidan dan daya hambat terhadap enzim siklooksigenase bunga rosela menunjukkan bahwa kandungan ekstrak bunga rosela mampu menghambat enzim siklooksigenase. ${ }^{11}$ Antioksidan dalam Flavanoid dapat mengurangi atau bahkan menghilangkan inflamasi dengan beberapa mekanisme yaitu mengikat radikal bebas secara langsung, melalui penghambatan terhadap nitrid oksida, menghambat adhesi leukosit pada dinding pembuluh darah dan interaksi dengan sistem enzim lainnya. ${ }^{12}$ Pada penelitian tersebut daya anti inflamasi ekstrak bunga rosela telah dibuktikan, namun demikian masih perlu diteliti, mekanisme yang melibatkan hambatan aktivitas siklooksigenase-2 dan infiltrasi neutrofil. Ekstrak bunga rosela mempunyai toksisitas yang sangat rendah, dosis toksis akut $\left(\mathrm{LD}_{50}\right)$ pada tikus adalah $5000 \mathrm{mg} / \mathrm{kg} \mathrm{BB} .^{13}$

Tujuan penelitian untuk mengetahui ekspresi COX-2 dan jumlah neutrofil fase inflamasi pada proses penyembuhan luka mukosa bukal setelah pemberin sistemik ekstrak etanolik rosela.

\section{METODE PENELITIAN}

Penelitian ini merupakan penelitian eksperimental laboratoris. Prosedur penelitian telah disetujui oleh Komisi Etik Fakultas Kedokteran Gigi, Universitas Gadjah Mada Yogyakarta melalui surat no. 363/KKEP/FKG-UGM/EC/2012.

Tanaman rosela, didapatkan dari perkebunan di Dusun Bulusari Desa Pojok Kecamatan Tarokan Kabupaten Kediri Jawa Timur. Tanaman rosela diambil bunganya dengan kriteria umur tanaman 
yang dipanen 5 bulan, dengan kriteria bunga rosela yang dipetik sudah masak, ditandai dengan adanya warna merah tua pada kelopak bunganya. Bunga rosela diidentifikasi di Laboratorium Biologi Farmasi Fakultas Farmasi, Universitas Gadjah Mada. Pembuatan eksrak bunga rosela dilakukan di LPPT unit I UGM Yogyakarta menggunakan metode penyarian perkolasi. ${ }^{14}$ Ekstrak rosela dibuat dalam dosis $500 \mathrm{mg} / \mathrm{kg} \mathrm{BB}$ tikus. ${ }^{15}$

Subjek penelitian menggunakan tikus putih galur Wistar usia umur 2 bulan, berat badan 250-300 gram dari Laboratorium Farmakologi, Fakultas Kedokteran Umum, Universitas Gajah Mada Yogyakarta. Tikus Wistar sebanyak 36 ekor diadaptasikan selama 7 hari di dalam kandang individual. Pembuatan perlukaan pada subjek diawali dengan prosedur anestesi dengan cara injeksi ketamin $\mathrm{HCl}$ secara intra muskular pada otot paha belakang dengan dosis $0,2 \mathrm{ml} / 250 \mathrm{gr}$ BB tikus. Perlukaan dibuat dengan cara meletakkan ujung punch biopsi diameter $3 \mathrm{~mm}$ pada mukosa bukal kiri atas dan ditekan sampai menembus epidermis. Jaringan yang sudah terpotong oleh punch biopsi dipotong dengan gunting bedah dengan ukuran $5 \mathrm{~mm}$ dari tepi luka dan kedalaman menembus epidermis. ${ }^{16}$

Subjek penelitian dibagi menjadi 3 kelompok yaitu 1) kelompok perlakuan, terdiri dari 12 ekor tikus wistar yang diberi perlukaan pada mukosa bukal, selanjutnya diberi ekstrak bunga rosela dengan dosis $500 \mathrm{mg} / \mathrm{kg}$ BB tikus. Pemberian ekstrak rosela dilakukan selama 4 hari dan diberikan sehari sekali setelah perlukaan. 2) Kelompok kontrol negatif terdiri dari 12 ekor tikus wistar yang diberi perlukaan dan hanya diberi saline sebagai placebo. Pemberian saline dilakukan sehari sekali selama 4 hari. 3) Kelompok kontrol positif, terdiri dari 12 ekor tikus yang diberi perlukaan pada mukosa bukal, selanjutnya diberi ibuprofen dengan dosis $20 \mathrm{mg} /$ $\mathrm{kg}$ BB tikus selama 4 dan diberikan sehari sekali setelah perlukaan. Pada hari ke-1, 2, 3, dan 4 setelah perlukaan masing-masing kelompok dikorbankan 3 ekor tikus. Dekapitasi pada tikus dilakukan dengan cara melakukan anastesi terlebih dahulu menggunakan ketamin $\mathrm{HCl}$ dengan dosis $0,2 \mathrm{ml} /$
250 gram BB tikus secara intra muskular pada otot paha belakang, selanjutnya dilakukan pengambilan jaringan mukosa bukal kiri atas sebanyak $5 \mathrm{~mm}$ dari teri perlukaan untuk dibuat blok parafin untuk pembuatan preparat histologis. ${ }^{16,17}$

Preparat selanjutnya diwarnai HematoxilinEosin (HE) untuk mengamati neutrofil dan imunohistokimia untuk mengevaluasi ekspresi COX-2. Prosedur pewarnaan imunohistokimia menggunakan bloking peroksidase dengan $\mathrm{H}_{2} \mathrm{O}_{2}$ $0,3 \%$ lalu pencucian dengan PBS 3 kali. Antigen retrievel dilakukan dengan pemanasan dalam citric buffer pH 6 sebanyak 2 kali @ 5 menit. Blocking non specific binding dengan cara mengaplikasikan background snipper selama 10 menit. Staining IHC proper dengan mengaplikasikan rabbit polyclonal COX-2 (Lab Vision, USA) perbandingan 1:800 selama 20 menit. Pencucian dengan PBS sebanyak 3 kali @ 5 menit. Aplikasi antibodi sekunder (biotinylated goat anti-polyvalent) selama 10 menit lalu pemberian Trek Avidin-HRP label selama 10 menit. Prosedur IHC dilanjutkan dengan inkubasi dalam pewarna Betazoid DAB (1:100 dalam substrat) selama 5 menit kromogen. Counterstain digunakan Hematoxylin mayers selama 1 menit. Prosedur diakhiri dengan mounting.

Pengamatan jumlah sel neutrofil dan ekspresi COX-2 pada jaringan ikat area tepi luka menggunakan mikroskop cahaya pembesaran 400 kali. Ekspresi COX-2 ditandai dengan adanya granula warna kuning kecoklatan dalam sitoplasma dan membran nukleus. Tiap preparat IHC diamati dalam 6 lapangan pandang dan dihitung rataratanya lalu dianalisis dengan two-way Anova dan LSD.

\section{HASIL PENELITIAN}

Hasil penelitian menunjukkan bahwa ekspresi COX-2 pada kelompok kontrol negatif, kontrol positif dan rosela $500 \mathrm{mg} / \mathrm{kg}$ BB tampak lebih rendah mulai hari ke-2 sampai hari ke-4 pengamatan. Rerata dan simpangan baku ekspresi COX-2 ditampilkan pada Gambar 1. 


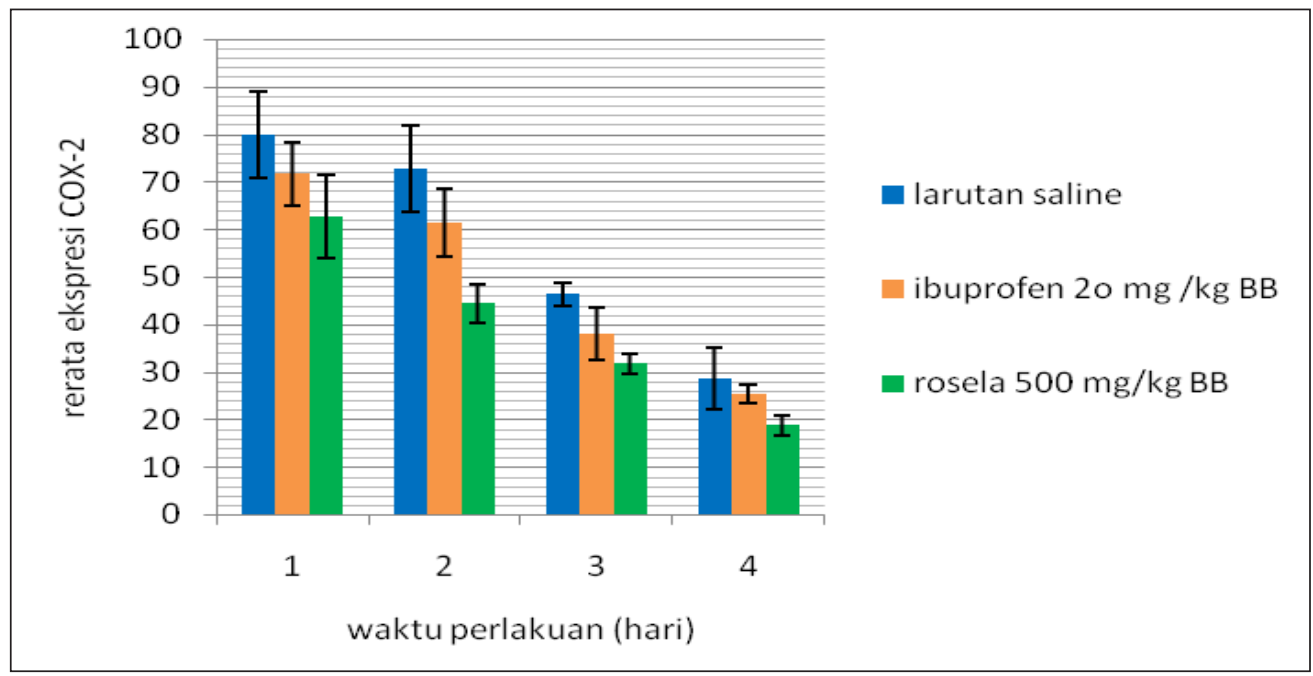

Gambar 1. Rerata dan simpangan baku ekspresi COX-2 hari ke-1 sampai ke-4 kelompok kontrol negatif, kontrol positif dan rosela $500 \mathrm{mg} / \mathrm{kg} \mathrm{BB}$

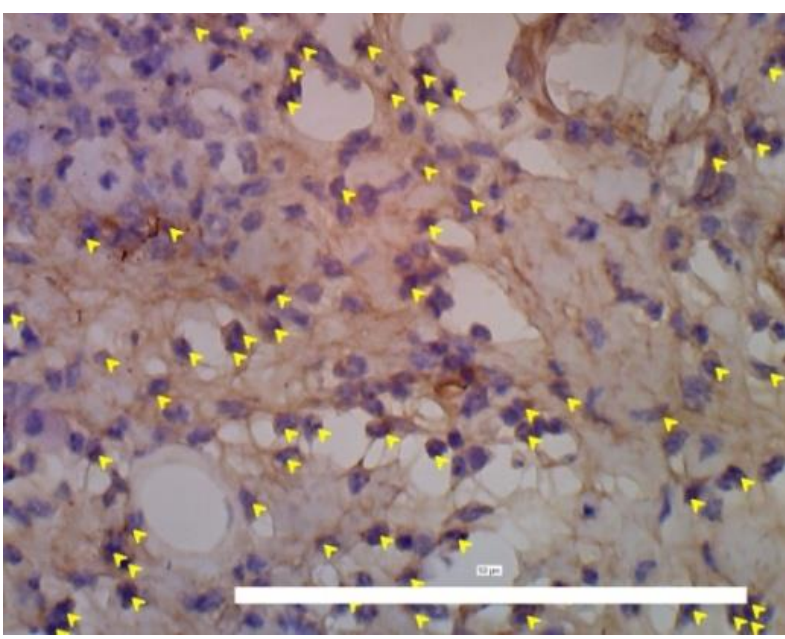

(A)

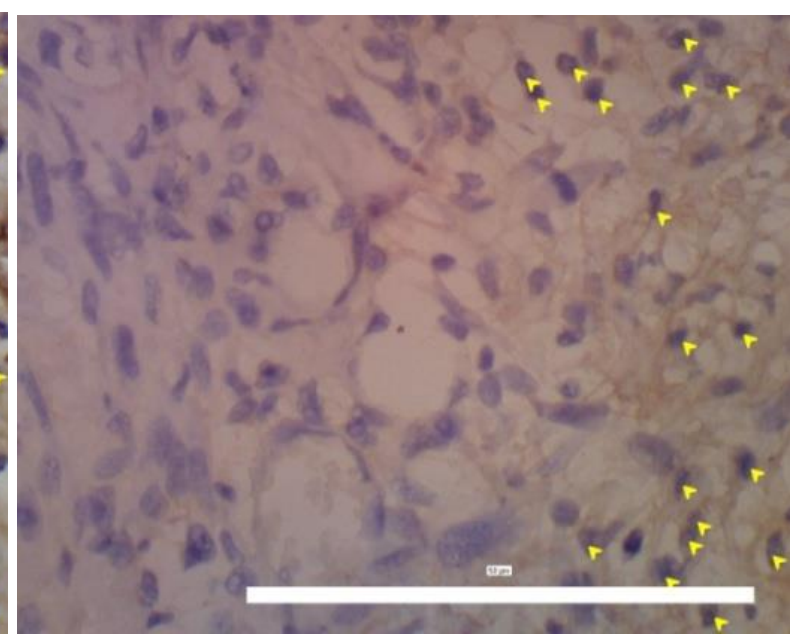

(B)

Gambar 2. Gambaran ekspresi COX-2 (anak panah kuning) kelompok rosela pada hari ke-1(A) dan hari ke- 4(B). Ekspresi COX-2 tampak lebih rendah pada hari ke-4

Hasil uji Two-way Anova ekspresi COX-2 menunjukkan nilai $(p)<0,05$, hal ini berarti terdapat perbedaan bermakna ekspresi COX-2 pada hari ke-1, ke-2, ke-3 dan ke-4 antara kelompok kontrol negatif, kontrol positif dan rosela $500 \mathrm{mg} / \mathrm{kg}$ BB. Gambaran mikroskopis ekspresi COX-2 pada kelompok rosela $500 \mathrm{mg} / \mathrm{kg}$ BB ditampilkan pada Gambar 2.
Hasil pengamatan jumlah neutrofil memperlihatkan terjadinya penurunan rerata jumlah neutrofil pada semua kelompok mulai hari ke-2 sampai ke-4 kecuali pada kelompok kontrol negatif pada hari ke-2 mengalami peningkatan. Rerata dan simpangan baku jumlah neutrofil ditampilkan pada Gambar 3. 


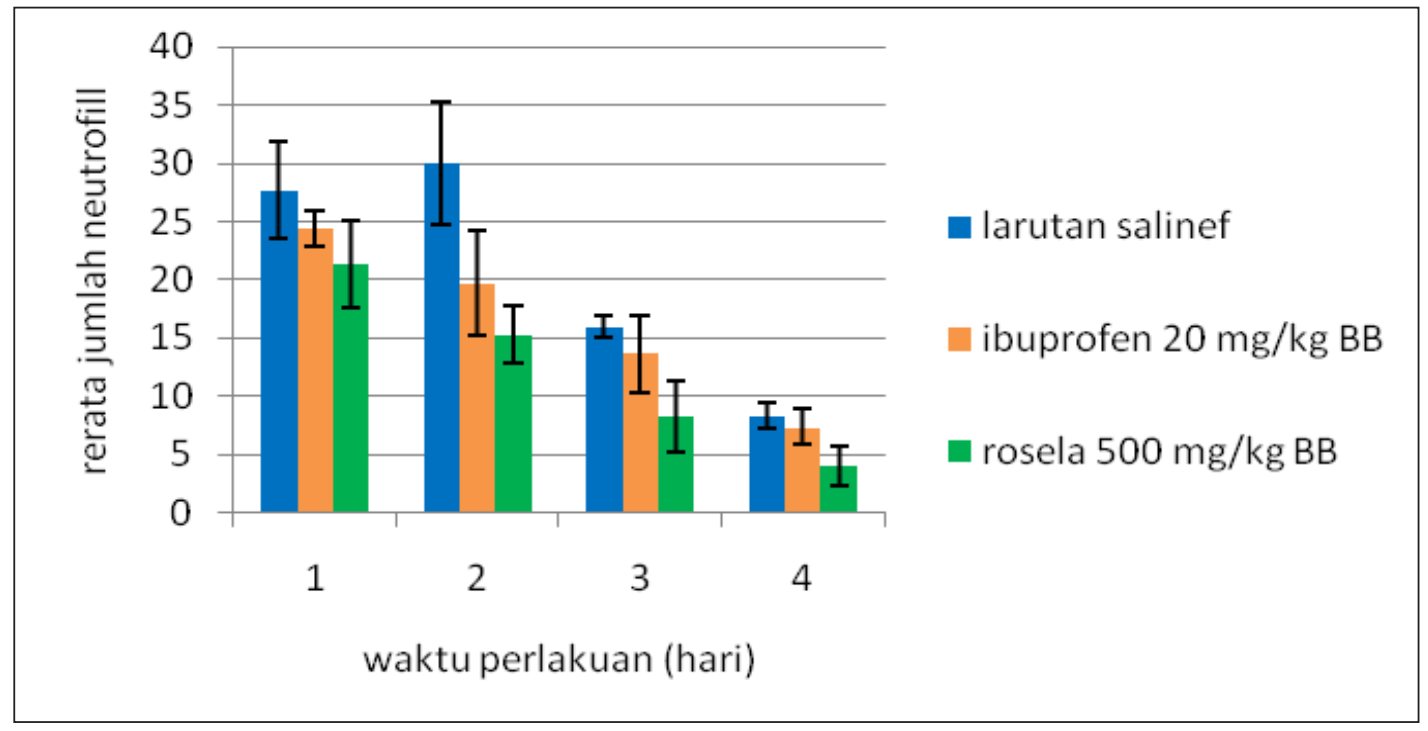

Gambar 3. Rerata dan simpangan baku jumlah neutrofil pada kelompok kontrol negatif, kontrol positif dan rosela hari ke-1 sampai ke-4

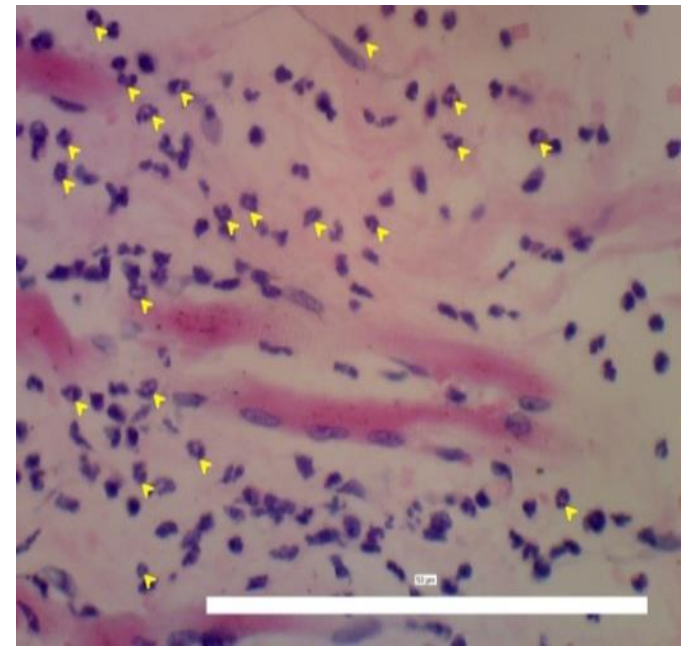

(A)

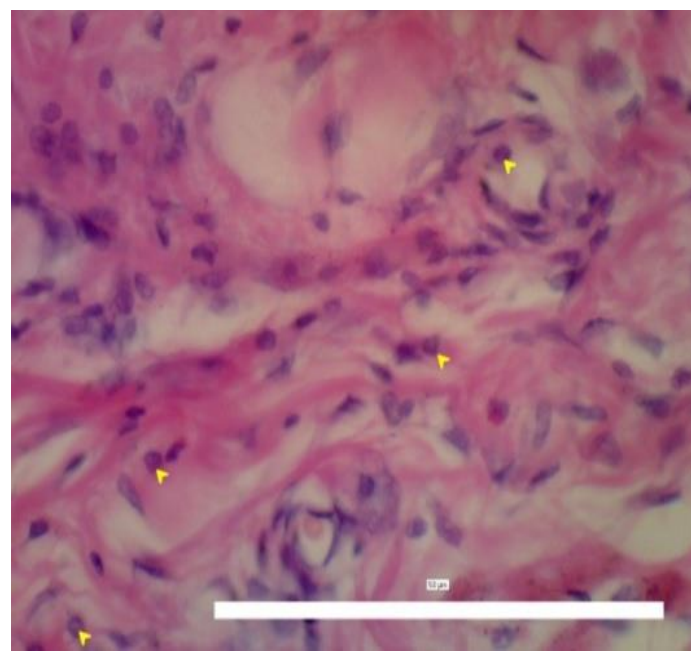

(B)

Gambar 4. Gambaran jumlah neutrofil (anak panah kuning) kelompok rosela pada hari ke-1 (B) dan hari ke-4 (A). Jumlah neutrofil tampak sedikit pada hari ke-4

Hasil uji Two-way anova jumlah neutrofil menunjukkan nilai $(p)<0,05$, hal ini berarti terdapat perbedaan yang bermakna jumlah neutrofil antara kelompok kontrol negatif, kontrol positif dan rosela $500 \mathrm{mg} / \mathrm{kg}$ BB tikus.

\section{PEMBAHASAN}

Proses inflamasi menyebabkan peningkatan mediator inflamasi, salah satunya protaglandin yang merupakan hasil biosintesis asam arakhidonat melalui jalur siklooksigenase. Peningkatan prostaglandin akan menstimuli syaraf nyeri dan meningkatkan respon inflamasi. ${ }^{16}$ Respon inflamasi harus dikendalikan karena adanya respon inflamasi yang terus menerus dan berlangsung lama akan menyebabkan terjadinya kerusakan jaringan yang semakin parah, meskipun respon inflamasi merupakan pertahanan terhadap adanya jejas dari luar. Penghambatan jalur siklooksigenase berguna 
untuk mengurangi atau menghilangkan gejala inflamasi. Pada jaringan yang cedera akan terjadi proses penyembuhan luka yang diawali dengan terbentuknya jendalan darah dan selanjutnya diikuti fase inflamasi pada hari ke-1 sampai ke-3, fase proliferasi pada hari ke-3 sampai ke-7 dan remodeling pada hari ke-7 sampai ke-14 setelah adanya jejas. ${ }^{18,19}$ Proses penyembuhan luka tidak akan terjadi apabila tidak ada inflamasi dan akan menjadi sumber nyeri. Hasil penelitian menunjukkan bahwa rerata ekspresi COX-2 setelah pemberian sistemik ekstrak etanolik rosela $500 \mathrm{mg} / \mathrm{kg}$ BB tampak lebih rendah sesuai waktu pemberian. Ekstrak etanolik rosela dapat menghambat ekspresi COX-2 dengan mekanisme sebagai berikut ekstrak etanolik rosela mempunyai kemampuan menghambat aktivasi NFkB sehingga menghambat sintesis IL-1 dan TnFa. Penghambatan sintesis IL-1 dan TnFa menyebabkan berkurangnya rangsangan pada fosfolipid membran sel, sehingga asam arakhidonat tidak dibebaskan dari fosfolipid membran sel oleh aktivasi fosfolipase. Keadaan ini menyebabkan berkurangnya sintesa protein COX-2 dan biosintesis prostaglandin berkurang sehingga respon inflamasi berkurang. ${ }^{2,22}$ Beberapa penelitian memperlihatkan flavanoid rosela terdiri dari senyawa-senyawa flavanol dan pigmen antosianin yang berperan sebagai antioksidan. ${ }^{8}$ Antioksidan dalam rosela mempunyai daya hambat terhadap aktifitas enzim siklooksigenase secara in vitro. ${ }^{11}$ Hasil penelitian juga menunjukkan jumlah neutrofil paling sedikit terjadi pada kelompok rosela. Hal ini diduga karena adanya kandungan flavanoid dalam rosela. Antioksidan dalam flavanoid tumbuhan dapat mengurangi bahkan menghilangkan inflamasi dengan beberapa mekanisme antara lain rosela akan menghambat aktivasi NFkB sehingga menghambat sintesa IL-1 dan TnFa. Penghambatan sintesa IL-1 dan TnFa menyebabkan tidak terjadinya vasodilatasi pembuluh darah dan peningkatan permeabilitas kapiler sehingga tidak terjadi aktivasi faktor komplemen $\mathrm{C} 5 \mathrm{a}$, dan menghambat adhesi neutrofil pada dinding pembuluh darah. Adhesi neutrofil pada dinding pembuluh darah merupakan awal dari gerakan neutrofil masuk ke dalam jaringan. Penghambatan adhesi neurofil pada dinding pembuluh darah menyebabkan infiltrasi neutrofil ke dalam jaringan turun sehingga inflamasi akan berkurang. ${ }^{2,12}$

Pengamatan klinis memperlihatkan penyembuhan luka menutup dengan sempurna pada hari ke-4 kelompok rosela. Proses penyembuhan luka akan lebih cepat pada jaringan dengan jumlah neutrofil yang lebih sedikit. Hal ini disebabkan neutrofil menghasilkan neutrofil protease elastase dan proteinase-3 yang mempunyai kemampuan memecah elastin dan matriks ekstra seluler. Adanya gangguan pada matriks ekstra seluler maka perbaikan epitel terganggu dan menghambat proses penyembuhan luka. ${ }^{19}$ Berbagai mekanisme flavanoid pada jaringan yang terkena jejas akan menyebabkan inflamasi menurun dan mempercepat proses penyembuhan luka.

\section{KESIMPULAN}

Pemberian ekstrak etanolik rosela dapat menghambat ekspresi COX-2 dan menurunkan jumlah neutrofil fase inflamasi pada proses penyembuhan luka.

\section{DAFTAR PUSTAKA}

1. Hamamoto T,Yabuki, Yamato O, Fujuki $M$, Misumi K, Matsumoto, Immunohistochemiccal Analysis of cyclooxygenase-2 induction during wound healing in dog skin. Res Vet Sci. 2009; 87: 349-54.

2. Robbins SL, Kumar V. Buku ajar patologi. alih bahasa, staf pengajar laboratorium patologi anatomik Fakultas Kedokteran Universitas Airlangga Surabaya. edisi 4. Jakarta: EGC; 1995. h. 29-65.

3. Gilroy DW, Colville-Nash PR, Willis D, Chivers $\mathrm{J}$, Inducible cyclooxygenase may have antiinflamatory properties, London: Departement of Experimental Pathology, St.barttholomew's \& Royal London School of Medicine and Dentistry; 1999. h. 5-6.

4. Gilman and Goodman, Pharmacological basis of therapeutics, USA: McGraw-Hill; 2001. h. 687-91. 
5. Prempeh ABA, Attipoe JM. In vivo inhibition of prostaglandin $\mathrm{E} 2$ production by crude aqueous exstract of the root bark of zanthoxylum xanthoxyloides. Ghana Med J. 2008; 42 (2): 85-88.

6. Greenberg MS, Glick M, Ship JA. Oral medicine. Hamilton: BC Decker Inc; 2008. h. 266-267.

7. Katzung BG. Basic and clinical pharmacology, alih bahasa staf dosen farmakologi Fakultas Kedokteran Universitas Sriwijaya. Edisi VI. Jakarta: EGC; 1998. h. 307-11, 558-66.

8. Maryani $\mathrm{H}$, Kristiana L. Khasiat dan manfaat rosela. Jakarta: PT. Agro Media Pustaka; 2008. h. 2-9, 23-33.

9. Mungole A, Chaturvedi A. Hibiscus sabdariffa I a rich of secondary metabolit. Int. J of Pharmaceu Sci Rev and Res. 2011: 6(1): 836.

10. Ali MdK, Ashraf A, Biswas NN., Karmakar UK, Afroz S. Antinociceptive, anti-inflamatory and antidiarrheal activities of ethanolic calycx extract of Hibiscus sabdariffa linn. (Malvaceae) in Mice. J Chin Med. 2011; 9(6): 626 - 31.

11. Cristian KR, Nir MG, Jackson JC, Antioksidant and cyclooksigenase inhibitory activity of sorrel (Hibiscus sabdariffa. J Food Comp and Analys. 2006; 19: $778-83$.

12. Nijveldt RJ, Nood EV, Hoorn DECV, Boelens PG, Norren KV, Leeuwen PAMV. Flavanoids: a review of probable mechanisms of action and potential application. Am J Clin Nutr 2001; 74: 418-25.

13. Okasha, Abubakar, Bako. Study of effect of aqueous Hibiscus sabdariffa Linn seed exstract on serum prolactin level of lactating female albino rats", Euro J F Sci Res. 2008; 22(4): 575- 83.

14. Information for faculty, office of the campus veterinarian. Rat drugs and dosages.
Washington State University: http:// Campusved.wsu.edu/ infofac/ ratdose. htm (diakses 29 oktober 2012).

15. Ansel HC, Pengantar bentuk sediaan farmasi. Jakarta: Universitas Indonesia; 1989. h. 60812.

16. Cao T. Daily administration of ibuprofen modifies neuroinflamation gene expression, but not neuroplasticity gene expression in traumatic brain injured rats. Kaleidoscope. 2010; 9(39): 1-4.

17. De Masi ECDJ, Rocha SR, Mocelina M, Faria JLGD. Wound healing in the jugal mucosa of rats with a cold blade scalpel and ultrasonic harmonic scalpel. Braz J Otorhinolaryngol. 2009; 75(3): 362-366.

18. Guyton AC. Human physiology and mechanisms of disease, alih bahasa Andrianto P. Jakarta: EGC; 1995. h. 53-4, 444.

19. Kumar V, Abbas AK, Fausto N, Mitchell R, Robbins. Basic Pathology. $8^{\text {th }}$ China: Saunders Elsevier; 2010. h. 45-8.

20. Jaafar SE. Wound healing as well as fibroblasts and neutrophil numbers in a skin exposed to infrared and electrical stimulation. J of Kirkuk University- Scientific Studies. 2011; 6(2): 50-62.

21. Kao Erl-Shyh, Hsu Jeng Dong, Wang ChauJong, Yang Su-Huei, Cheng Su-Ya, Lee HueiJane. polyphenol extracted from Hibiscus sabdariffa I. inhibited lipopolysaccharideinduced inflammation by improving antioxidative condition and regulating cyclooxygenase-2 expression", bioschi. Biotechnol Biochem. 2009; 73(2): 385-90.

22. Dovi JV, Szpaderska AM, DiPietro LA. Neutrofil function in the healing woung: adding insult to injury, burn and shock trauma institute. Illinois, USA: Departement of Surgery, Loyoda University Medical Center Maywood; 2004. h. $275-80$. 